Безумовно, ті фундаментальні положення, які в минулому визначали розвиток профтехосвіти в XXI ст., зазнають суттєвих змін. Протягом усього періоду функціонування профтехосвіти часто абсолютизувалась іiі єдина мета - забезпечення галузей народного господарства кваліфікованими робітничими кадрами. На сучасному етапі мета цієї системи суттєво розширюється й передбачає створення умов для професійної самореалізації особистості, задоволення іiі потреб у професійних, освітніх послугах упродовж усього життя [9, с. 63].

Перспективу подальших досліджень убачаємо у визначенні педагогічних умов реалізації ідеї професійної орієнтації в умовах вітчизняної профільної школи.

\title{
Література
}

1. Антипова Е. И. Ориентация учащихся на педагогическую профессию / Е. И. Антипова // Советская педагогика. $-\quad$ 1986. $-\quad$ № 9. $-\quad$ С. 38-42. 2. Антология педагогической мысли Росии первой половины XIX в. - Москва : Педагогика, 1990. - 608 с. 3. Бібік Н. Науково-методичний супровід у профільній школі / Надія Бібік, Михайло Бурда // Освіта України. - 2004. - 17 серп. (№ 62/63). - С. 4-6. 5. Історія української школи i педагогіки : [хрестоматія] / [В. Г. Кремень (ред.), О. О. Любар (упоряд.)]. - Київ : Знання, 2003. - 766 с. 6. Концепція державної системи професійної орієнтації населення освіти [Електронний ресурс]. - Режим доступу: http://zakon4.rada.gov.ua/laws/show/842-2008\% D0\%BF 7. Концепція профільного навчання в старшій школі // Інформаційний збірник Міністерства освіти і науки України. - 2003. - № 24.- С. 3-15. 8. Любар О. О. Історія української педагогіки: [навч. посіб.] / О. О. Любар, М. Г. Стельмахович, Д. Т. Федоренко ; ред. О. О. Любара. - Київ : Знання; КОО, 2003. - 450 с. 9. Мантуленко С. В. Формування готовності майбутніх учителів географії до профільного навчання старшокласників : дис. ... кан. пед. наук. : 13.00.04 / Мантуленко Світлана Вікторівна. - Кривий Ріг, 2014. - 255 с. 10. Сірополко С. Історія освіти в Україні / підготував Ю. Вільчинський. - [2-е вид.]. Львів : Афіша, 2001. - 664 с. 11. Сухомлинський В. О. Вибрані твори : в 5-ти т. / Василь Олександрович Сухомлинський. - Т. 5 : Статті. - Київ : Рад. шк., 1977. - 639 с.

УДК 372.48:373.1(477)

Володимир Бугрій

\section{ЗАВДАННЯ, ЗМІСТ ТА СТРУКТУРА ІСТОРИЧНОЇ ОСВІТИ В НАВЧАЛЬНИХ ПЛАНАХ І ПРОГРАМАХ ТРУДОВОЇ ШКОЛИ В УКРАЇНІ (20-ті рр. ХХ ст.)}

Бугрій В. С. Завдання, зміст та структура історичної освіти в навчальних планах $\mathrm{i}$ програмах трудової школи в Україні (20-ті рр. ХХ ст.).

Статтю присвячено аналізу завдань, змісту та структури історичної освіти у трудовій школі в Україні у 20-ті pp. XX ст. Встановлено, що в навчальних планах і програмах історична освіта підпорядковувалася головному завданню, яке ставилося перед трудовою школою - підготовці майбутніх працівників промисловості чи сільського господарства, їх вихованню в дусі відданості соціалістичним ідеалам. Історичні знання обмежувалися вивченням трудової діяльності людей і радянської дійсності як абсолютної цінності у порівнянні з минулим. У зв'язку з цим у програмах 1920-х рр. історія як самостійний шкільний предмет скасовувалася, а історичні знання були інтегровані спочатку в курс історії культури, а пізніше в курс суспільствознавства.

Ключові слова: історична освіта, трудова школа, навчальна програма, комплексна програма, суспільствознавство. 
Бугрий В. С. Задания, содержание и структура исторического образования в учебных планах и программах трудовой школы в Украине (20-е гг. XX в.).

Статья посвящена анализу задач, содержания и структуры исторического образования в трудовой школе в Украине в 20-е гг. ХХ ст. Установлено, что в учебных планах и программах историческое образование подчинялось главной цели, которая ставилась перед трудовой школой - подготовке будущих работников промышленности или сельского хозяйства, их воспитанию в духе преданности социалистическим идеалам. Исторические знания ограничивались изучением трудовой деятельности людей и советской действительности как абсолютной ценности в сравнении с прошлым. В связи с этим в программах 1920-х гг. история как самостоятельный школьный предмет отменялась, а исторические знания были интегрированы сначала в курс истории культуры, а позже - в курс обществоведения.

Ключевые слова: историческое образование, трудовая школа, учебная программа, комплексная программа, обществоведение.

Buhrii V. S. The tasks, content and structure of historical education in curricula and syllabi of labour school in Ukraine ( in the twentieth of the XX century).

The article is aimed at analyzing the tasks, content and structure of historical education of labour school in Ukraine ( in the twentieth of the XX century). The historical education in the curricula and syllabi was determined to comply with the main goal of the labor school as training future employees of industry and agriculture in the spirit of devotion to socialist ideals. Historical knowledge was limited to the study of labour activity of people and soviet reality as an absolute value in comparing to the past. In this regard, in the programs of the 1920s. history as a separate subject in school was canceled. Historical knowledge was integrated at first in the course of history of culture and later in the course of social science.

Key words: historical education, labour school, syllabus, complex program, social science.

Розвиток демократичних процесів в Україні, зростання духовного самовизначення українського народу вимагають створення нової системи історичної освіти, заснованої на національно-культурних традиціях 3 урахуванням прогресивних досягнень вітчизняного досвіду. Нині здійснюється активний перегляд ставлення до розвитку вітчизняної історичної освіти та їі важливих здобутків на різних етапах.

До аналізу освітніх процесів 20-х pp. XX ст. звертаються сучасні українські дослідники В. Борисов, Л. Войтова, О. Пометун, Т. Самоплавська, В. Удод, К. Чадаєва, В. Яремчук та ін. Разом з тим, можна констатувати, що окремі питання розвитку історичної освіти у 20-х рр. ХХ ст. поки що не стали предметом усебічного дослідження. Тому об'єктивні потреби вивчення розвитку шкільної історичної освіти, можливість використання здобутків того часу в практиці навчання історії в загальноосвітній школі зумовлюють актуальність такого роду досліджень.

Mema cmammi - проаналізувати завдання, зміст і структуру історичної освіти у навчальних планах і програмах трудової школи в Україні у 20-х рр. XX ст.

Із початком 1920-х рр. відбувається становлення радянської системи загальної освіти, основою якої проголошувалася трудова школа. Положення про неї було прийнято влітку 1919 р. і передбачало зміну освітніх завдань і методів викладання. Оскільки трудова школа мала готувати майбутніх працівників промисловості чи сільського господарства, то 
пріоритет надавався професійній підготовці, а не засвоєнню системи знань. В Україні було ліквідовано старші класи середньої школи (8-9) і створено семирічки 3 напівпрофесійним ухилом [5, с. 18]. Відповідно до нової концепції загальної освіти розпочалася перебудова нормативних документів школи.

Улітку 1920 р. Народний комісаріат освіти України уперше видав навчальний план єдиної семилітньої трудової школи на 1920-1921 навчальний рік. У ньому передбачалося викладання історії із суспільствознавством у 4-7 класах. На цей курс виділялося 8 годин на тиждень. Через відсутність пояснювальної записки до навчального плану на місцях його розуміли по-різному, на власний розсуд наповнюючи конкретним змістом. У межах цього курсу викладалися політграмота, історія класової боротьби, історія України, радянська Конституція. Наприклад, органи освіти Роменського повіту Полтавської губернії пропонували школам «Програму соціально-політичної пропедевтики для 7-річної трудової школи (6-7 класи)». У ній передбачалися заняття за такими темами:

\section{6 клас}

1. Загальні відомості (перше півріччя).

2. Радянська Конституція (друге півріччя).

7 клас

1. Історія Інтернаціоналу (перше півріччя).

2. Державнокомуністичне будівництво (друге півріччя) [3, арк. 32].

У запропонованій програмі домінували теоретичні історичні знання. Зокрема, протягом навчання у 6 класі учні повинні були засвоїти велику кількість складних для свого віку понять: натуральне господарство, взаємообмін, капіталістичний устрій, середньовікові цехи, професійні організації нових часів, диктатура пролетаріату, комунізм [3, арк. 32].

Суспільно-політичні теоретичні поняття мали замінити фактичний і біографічний матеріал, що переважав у навчанні історії в період царської школи. Як зазначалося у «Програмах для шкіл по предметам», така побудова змісту навчання зосереджувала увагу дітей на тих процесах народного життя, які вважалися головними і завжди обминалися: економічний устрій, соціальні відносини, побут. На думку керманичів освіти, «усе це значно більше торкається безпосереднього життя дитини, бо з ними вона має справу на кожному кроці, ніж далекі походи в різні землі, про які учень не має уявлення, героїчні вчинки та політична діяльність так званих «великих» людей, що живуть і працюють в умовах та оточенні, абсолютно чужих нашим дітям» [3, арк. 46].

Отже, замість традиційних курсів античності і середніх віків до змісту історичної освіти вводилися малозрозумілі схеми із політичної економії та соціології, досить далекі від дитячого сприйняття. Окрім того, у процесі викладання історії вчителі повинні були надавати перевагу практичній діяльності, оскільки трудові процеси вважалися головними засобами подолання формалізму і схоластики навчання, підвищення цікавості учнів до нових знань. Відповідно до такого підходу необхідно було максимально залучати дітей до різного роду графічно-об’ємної діяльності (ліпка, виготовлення аплікацій, моделей, панорам). Наприклад, у «Бюлетені» Полтавського губернського відділу освіти вказувалося, що це могли бути вирізані із паперу і розмальовані картини, поклеєні із дерева чи картону, або зроблені із глини моделі будинків, фігури людей, зброя, реманент. Наголошувалося на тому, що найбільш доцільно таку працю проводити колективно, «нехай клас поділиться на групи і сам розподілить працю» [1, с. 7].

Отже, уже в перших нормативних документах трудової школи очевидною стає тенденція недооцінки значення основ історичної науки, які мали виконувати лише службову 
роль стосовно трудових процесів. Щоправда, позитивним було те, що в нових умовах місцеві органи освіти орієнтували школи до детального вивчення історії рідного краю. Так, у «Пояснювальній записці до програми історії в єдиній трудовій школі соціального виховання», виданій Полтавським губерніальним відділом народної освіти у 1920 р., говорилося: «Відповідну роль у всьому курсі потрібно надати й історії Полтавщини: всі історичні процеси загальноукраїнські бажано простудіювати на матеріалі місцевім, а потім поширити їх на всю Україну і взагалі, історію місцеву необхідно використовувати у всіх тих випадках, коли це можливо» [3, арк. 45].

У 1921 р. під керівництвом М. Покровського було підготовлено нову навчальну програму для Російської Федерації. Вона стала використовуватися і в Україні. У ній частини попередніх програм (історія культури, нова і новітня історія, основи економічної науки, історія соціалізму) об'єднувались в одну дисципліну- суспільствознавство. Автори програми аргументували це тим, що «при такому синтезі не лише скорочується час на навчання, але й органічніше виділяється тісний зв'язок окремих елементів історичного життя суспільства» [8, с. 89].

Програма із суспільствознавства була більшою мірою деталізованою, розпланованою за роками навчання і будувалася за принципом історико-хронологічної послідовності від найдавніших часів. Набагато більш вдало були представлені фактичні і теоретичні знання. У програмі навчальний матеріал розподілявся за трьома змістовими лініями: всесвітня історія, історія України, історія Росії. Для прикладу розглянемо зміст навчального матеріалу для 6 класу:

Всесвітня історія: Економічний переворот у Західній Європі. Гуманізм. Реформація. Тридцятилітня війна. Абсолютна монархія, занепад станово-представницьких органів. Нова економічна політика - меркантилізм. Франція на початку 17 ст., Фронда, Людовик 15. Англія на початку 17 ст., Тюдори, Стюарти, Кромвель.

Історія України: Гетьманщина, Руїна. Україна при Мазепі. Лівобережна Україна 3 початку 18 ст. Суспільні класи, обмеження козацьких прав. Падіння української Автономії. Ліквідація гетьманської влади. Соціальні реформи Катерини в Україні. Економічний розвиток Східної України. Західна Україна під владою Польщі у 18 ст. Гайдамацькі повстання і Коліївщина.

Історія Росії: «Смутні часи», Мінін і Пожарський, обрання Романова. Земський собор 1648 року і кодекс 1649 року. Петро I, Північна війна. Катерина I, Пугачовщина і Разінщина [3, арк. 51-53].

За цією програмою навчання історії тривало до 1924 р., коли відбулося чергове реформування радянської концепції загальної освіти. Були випущені нові програми для семилітньої школи, складені на основі проекту Державної Вченої Ради Народного комісаріату освіти під керівництвом Н. Крупської. Вони отримали назву комплексних. Комплексні програми базувалися на таких принципах: 1) не система наук, а життєві комплекси повинні лежати в основі шкільного навчання; 2) не знання, а уміння добувати знання, творча самодіяльність учнів - головне у шкільному навчанні. Виходячи із цих принципів, на першому концентрі школи (1-4 класи) взагалі не передбачалося навчання за окремими предметами. Замість них дітей ознайомлювали із життєвими явищами, об’єднаними за трьома розділами: природа, праця, суспільство. Епізодичні історичні знання були представлені у так званих загальних темах: «Ленський розстріл», «Паризька Комуна», «Кривавий тиждень», «Жовтнева революція» та ін.

Отже, від історії як наукової системи творці комплексних програм відмовлялися, 
допускаючи лише історичні екскурси у зв'язку з окремими суспільними темами. 3 одного боку, революційне значення такого підходу полягало в тому, що навчання здійснювалося не за допомогою книги, а завдяки спостереженням за навколишнім життям у селі, місті, окрузі. Але 3 іншого боку, навчання, орієнтоване на вивчення із року в рік одних i тих же революційних тем, надокучувало дітям і не сприяло формуванню історичної перспективи.

На другому концентрі школи (5-7 класи) зберігалося викладання суспільствознавства окремим предметом, у курсі якого історичні знання мали узагальнений, соціологічний характер. Як підкреслювалося в педагогічних виданнях того часу, «зовсім не значить, як дехто думає, що в суспільствознавстві мусять бути систематичні курси окремих наукових дисциплін - історії та інше. Суспільствознавство ж бо не є конгломератом суспільних наук, воно є нове, спеціальне, синтетично збудоване для потреб нашої школи, для здійснення виховних завдань. Тому-то при побудові програми з суспільствознавства треба брати до уваги не тільки вимоги історичної науки, а й низку педагогічних, педологічних і виховних завдань» [6, с. 82].

Відповідно до навчальних планів на суспільствознавство відводилося по 5 год. на тиждень. Виходячи із загального розподілу комплексних тем, програма із суспільствознавства передбачала п'ятий рік навчання для міських шкіл із характеристики сучасних форм обміну, потім переходила до характеристики початкових форм обміну 3 моменту його зародження серед людей і простежувала його еволюцію в подальшому. Сільський варіант розпочинався з аналізу поняття про товар, потім розглядалися форми обміну і на їх фоні визначав економічні відносини міста і села. Далі, як і в міському варіанті, передбачалось вивчення сучасних господарських взаємовідносин села і міста, порівнюючи їх 3 дореволюційними. Головними даними про економічну політику радянської влади завершувалося вивчення суспільствознавчого матеріалу в першому триместрі. У другому триместрі п’ятого року навчання програма давала відомості про техніку організації праці на фабриці (міський варіант) і в сучасному селі (сільський варіант), після чого вивчалась еволюція техніки і господарства, паралельно розглядались соціально-економічні форми суспільного життя, розпочинаючи з первісних і завершуючи сучасними. Третій триместр п’ятого року навчання планував знайомство учнів з історією сільського господарства на матеріалі історії України.

На шостому році навчання тривало в першому триместрі ознайомлення учнів 3 історією сільського господарства на матеріалі історії України, іiї селянських рухів, пов'язаних із зміною господарських відносин. Історія українських селян порівнювалася 3 історією російських. Усі історичні знання про село завершувалися періодом остаточного розпаду кріпацтва. У другому і третьому триместрах програма міських і сільських шкіл передбачала вивчення історії Західної Європи і Росії епохи промислового капіталу.

Сьомий рік навчання охоплював матеріал з епохи фінансового капіталізму (перший триместр), про досягнення Жовтневої революції (другий триместр), про перспективи світової революції (третій триместр) [7, с. 47-60].

Пріоритетне місце в курсі суспільствознавства відводилося матеріалу сучасного життя, а історичні факти вводилися лише задля більш доступного його тлумачення. Одразу стали очевидними вади такого підходу. Так, український методист Ф. Гофман звертав увагу на те, що розуміння суспільствознавства виключно як вивчення сучасності вело лише до опису фактів, а не пояснення дійсності [2, с. 37].

Окрім того, дидактичний історичний матеріал у курсі суспільствознавства брався переважно з підручника, домінуючою залишалася книжно-лекційна форма навчання. Про це 
свідчили документи органів освіти. Так, методичний комітет Роменської округи у своїх тезах від 6 червня 1926 р. підкреслював , «що стосується суспільствознавства, то воно й до цього часу в більшості шкіл залишається словесним, догматичним, а не дослідним, у цьому напрямку й до цього часу панує схоластичність старої школи» [4, с. 2].

Слід зазначити, що постійно здійснювався процес удосконалення комплексних програм. Зміни стосувалися і курсу суспільствознавства. Так, з 1929 р. суспільствознавчий та історичний матеріал вивчався окремо. Наприклад, для 5 класу передбачалося опрацювання таких історичних тем: 1. Зародження феодалізму в Україні. 2. Розвиток феодалізму, торгівлі та закріпачення селянських мас Західної України в XV i XVI ст. 3. Гайдамаччина і Коліївщина. 4. Русифікаторська політика російського самодержавства [9, с. 14-33].

Водночас складність викладання матеріалу за комплексними темами, відсутність предметного вивчення наук, призводила до безсистемності знань учнів та неефективного використання шкільного часу. Учні не отримували загального уявлення про історичний процес. Критикувалися програми й істориками-методистами. Вони вказували на те, що комплексне навчання не давало ні необхідних формальних знань, ні навичок суспільного виробництва. Наприклад, О. Кулінич у своїй статті «Програмні матеріали 3 суспільствознавства старшого концентру» писав: «Задача історичної частини суспільствознавства, на нашу думку, полягає не лише в тому, щоб дати нашим підліткам знання фактів, а ще й цілісне уявлення історичного процесу. Без історичного підходу дитина не зможе достатньо уявляти хід розвитку суспільства, а значить, i не зможе уявити перспектив, що неминуче з цього суспільного розвитку випливають» [6, с. 83]. У подальшому дискусія навколо комплексного викладання зумовила зміну педагогічної концепції в СРСР і в Україні на початку 1930-х рр.

Отже, $з$ 1920-х рр. в Україні розпочалася розбудова трудової школи із 7-річним навчанням. Вона передбачала зміну завдань, змісту та структури загальної освіти. Аналіз навчальних планів і програм свідчить, що історична освіта підпорядковувалася головному завданню, яке ставилося перед трудовою школою- підготовці майбутніх працівників промисловості чи сільського господарства, їх вихованню в дусі відданості соціалістичним ідеалам. Історичні знання обмежувалися вивченням трудової діяльності людей і радянської дійсності як абсолютної цінності у порівнянні з минулим. У зв'язку з цим у програмах 1920-х рр. історія як самостійний шкільний предмет скасовувалася, а історичні знання були інтегровані спочатку до курсу історії культури, а пізніше - курсу суспільствознавства. До цих курсів, окрім історії, включалися ще й політекономія, соціологія, радянська Конституція. Конкретний зміст та обсяг історичної інформації визначався в кожній школі на власний розсуд. Заміна історичного курсу на абстрактно-соціологічний схематизм, далекий від дитячого розуміння, призвела до безсистемності знань учнів та слабкого розуміння ними особливостей історичного процесу.

\section{Література}

1. Бюлетень губерніального відділу народної освіти на Полтавщині. - Ч. 4, серпень 1922. - 32 с. 2. Гофман Ф. Суспільствознавство в старших групах трудової школи / Ф. Гофман // Радянська освіта. - 1926. - № 2. - С. 36-44. 3. Держархів Сумської області, ф. Р5600, оп. 1, спр. 96, арк. 32-55. 4. Держархів Сумської області, ф. Р-6058, оп. 1, спр. 33, арк. 2-4. 5. Кодекс законів про народну освіту УРСР. - Харків : Вид-во Наркомосу УРСР, 1922. - 120 с. 6. Кулінич О. Програмні матеріали 3 суспільствознавства старшого концентру / О. Кулінич // Шлях освіти. - 1930. - № 3. - С. 82-88. 7. Програма другого концентру для сільських і міських трудових шкіл.- Харків: ДВУ, 1926.- 119 с. 
8. Программы для 1 и 2 ступени семилетней единой трудовой школы. - Москва : ГИЗ, 1921 356 с. 9. Програмні матеріали для 2-го концентру трудових шкіл. - Харків : Народний учитель, 1929. - 278 с.

Аліна Волощук

\section{СТАНОВЛЕННЯ ХУДОЖНЬОЇ ОСВІТИ НА ЗАКАРПАТТІ В ПЕРШЙ ПОЛОВИНІ ХХ СТОЛІТТЯ}

Волощук А. В. Становлення художньої освіти на Закарпатті в першій половині ХХ століття.

У статті розкриваються етапи становлення художньої освіти на Закарпатті в першій половині XX століття. Акцентовано увагу на тому, що педагогічна діяльність і плідна творчість професійних художників А. Ерделі та Й.Бокшая надали потужного імпульсу створенню закарпатської школи живопису.

Ключові слова: художня освіта, образотворче мистецтво, закарпатська школа живопису, естетичне виховання, художня школа.

Волощук А. В. Становление художественного образования на Закарпатье в первой половине XX столетия.

В статье раскрываются этапы становления художественного образования на Закарпатье в первой половине XX века. Акцентировано внимание на том, что педагогическая деятельность и плодотворное творчество профессиональных художников А. Ердели и Й. Бокшая дали мощный импульс для создания закарпатской школы живописи.

Ключевые слова: художественное образование, изобразительное искусство, закарпатская школа живописи, эстетическое воспитание, художественная школа.

Voloshchuk A. V. Formation of artistic education in Transcarpathia in the first half of the $20^{\text {th }}$ century.

The stages of artistic education development in Transcarpathia in the first half of the $20^{\text {th }}$ century are revealed. It is emphasized that pedagogical activity and oeuvre of such professional artists as A. Erdely and J. Bokshai gave powerful impulse to creation of Transcarpathian painting school.

Key words: artistic education, fine art, painting school of Transcarpathia, aesthetic education, school of art.

Нині проблема вивчення історії становлення художньої освіти на Закарпатті, а також ролі видатних діячів освіти і мистецтва в цьому процесі $\epsilon$ актуальною, оскільки цілеспрямоване проникнення в логіку та структуру розвитку художньої освіти на Закарпатті не лише поглиблює розуміння еволюції цього процесу у ХX столітті, а й допомагає усвідомити їі місце, закономірності, тенденції розвитку в загальноукраїнському вимірі.

Образотворчі надбання Закарпаття початку XX століття досліджувалися науковцями В. Бадяком, Л. Владичем, С. Жупанином, В. Курильцевою, В. Мартиненком, І. Небесником, Г. Островським.

Mema cmammi полягає у спробі простежити основні віхи становлення закарпатської школи живопису, проаналізувати роль художників-педагогів у формуванні мистецького 